\title{
Resilience in Flood by Innovative, Community-Serving Engineering Solutions
}

\author{
Arash Rahmatian ${ }^{1 *}$ and Jacob Lipp ${ }^{2}$ \\ ${ }^{1}$ Associate Professor of Structural Engineering, University of Houston Downtown, Houston, Texas, USA \\ ${ }^{2}$ Director University Advancement, University of Houston Downtown, Houston, Texas, USA
}

Submission: October 10, 2020; Published: October 23, 2020

*Corresponding author: Dr. Arash Rahmatian, Associate Professor of Structural Engineering, University of Houston Downtown, Houston, Texas, USA

\section{Introduction}

Over the last 20 years, communities in and around Houston, Texas have seen a number of major flooding events including, most notably, Tropical Storm Allison in 2001 and Hurricane Harvey in 2017. In each of these instances, flooding limited the ability of individuals and families to responsibly evacuate high-risk areas in a self-sufficient manner, while straining public resources as first responders worked to assist those who are physically incapable of seeking safety on their own. Hurricane Harvey proved to be the second most expensive natural disaster in American history, causing more than 125 billion dollars in damage throughout the city, damaging more than 200,000 homes, and displacing upwards of 30,000 individuals. In addition to the massive devastation related to the aforementioned generational rainstorms, separated by sixteen years, certain parts of the city have had to grapple with flooding that has become increasingly routine. While these storms may not have held the national attention, Houstonians will recall the damage of 2015's Memorial Day Flood, 2016's Tax Day Flood, as well as Tropical Storms Imelda in 2019, and Beta in 2020. While several researchers around the world have studied applications of building technologies in earthquake protection, only limited solutions related to civic flood resilience have been examined to date. Outfitting targeted communities with a practical, attractive resource, in applications of floating concrete technology may serve to improve community resilience capabilities of civic infrastructure through multiple iterations, proving the functionality of this concept as defined in the following projects.

\section{Project Subject}

The primary objective of this project is the practical application of fiber reinforced lightweight concrete in innovative, communityfocused solutions. All constituent materials deployed in this project are environmentally friendly, and principally constructed of lightweight concrete and fiber polymer, resulting in no hazards or threats to users. These materials result in cost effective, durable, and easily replicable solutions with the possibility for application in any region. The light weight of these products make for easier shipping and installation and the durability of concrete makes them relatively maintenance-free.

Barrier Walls: Problems related to high flood-risk cities not only impact residential and commercial infrastructure but also endanger city facilities, resulting in inefficient emergency response and lapses in service. With applications related to the protection of property from floodwaters, protecting cars from flooding, acting as a barrier for highways and underpasses, and purposes such as the construction of temporary recreational water features in public spaces, the design of these barrier walls allows for the possibility to custom build for any level of inundation, and resistance capacities can be increased for higher water tables by adjustments to the foundation wall and shell size. In this study buoyancy force over a hollow section of a pre-cast lightweight floating reinforced concrete element triggers movement of a solid wall vertically. Water flow is blocked by a pre-installed polymer sealant between barrier walls and a pre-cast foundation. The design of the hollow section walls and its "U" box foundation has the potential to resist waters rising as high as 4 feet. The hollow barrier wall slides in $U$ box when floated and sealed at the edge of " $U$ " foundation which its details is beyond scope of this short report.

All segments are pre-cast, reinforced concrete which are submerged in the exterior perimeter of the project site, allowing for barrier walls to rise along with the level of water and to return underground as waters recede. As a result no physical impediment or aesthetic obstacle is created for entering to the property during dry days when embedded below the ground level. This approach provides significant cost advantage in comparison to the other methods such as raising the foundation of a building, and represents a less labor intensive solution than the use of temporary sand bags. Organizations charged with the protection and restitution of the public, such as FEMA, municipalities, and insurance providers may see benefits related to reduced damages 
as well as evaluation, remediation and flood aftermath costs. Certain facilities, such as hospitals, communication infrastructure and water treatment plants play such a critical role which support other facilities and their ability to remain online and in service. Similarly, the vital role of surface transportation in emergency response points to opportunities for implementation of these solutions by relevant government agencies to protect highways, as well as valley roads and underpasses where water flow can present clear risks to life, health and safety.

This technology can also contribute to the flood-proofing of homes through the installation of barrier walls around property, facilitating the safe storage and flood- resistant parking options for automobiles. This would likely add considerably to the market value of properties and adding resilience to high-risk regions. Whereas commercially available flood gate solutions tend to be controlled manually or are equipped with electronic devices and sensors, this technology does not necessitate any electrical, sensor or computing technology during flooding and can easily be manufactured, operated and installed for any duration and any anticipated level of water. All applied materials and components in this technology are durable and have no replacement requirement. Interlocking precast segmental concrete elements can be connected on-site, underground, not unlike the popular LEGO toy blocks.

Civic Furniture: Functioning as an aesthetically pleasing bench or table under conventional conditions, these items have the ability to float and serve as a raft in the event of a flood. This design includes an embedded paddle and can protection for users and their belongings from high levels of water.

Safe Zone Platform: Fit to the size of a truck with the floating capacity of the truck's weight, this floating concrete platform is designated for high level water regions and is identified with signage noting the details of its capacity, as well as the location where the vehicle is to be parked.

Car-Boat Transformer: These concrete platforms convert a car to a boat by transferring the force from the front wheels to an embedded propeller. This model is exceptional for any level of water and a driver has the ability to maneuver in and out of water. Built to the size of a truck, this product can be towed for use at required areas. An application of a car-boat for transporting EMS (Emergency Medical Services) and other first responders during flood events represents significant potential to effectively activate non-deployed human resources from emergency response entities which would otherwise have to cope with potentially disastrous service interruption.

Floating Emergency Roads: This pavement structure can be designed such that several pieces of floating slab are connected together, laying at- or near-grade during most circumstances. As flood waters rise, EMS and other first responder vehicles easily pass over the water via this floating roadway. These can be placed in anticipated high-water areas, such as underpasses, and valleys in highways. Project teams for specific implementations can determine whether these should be designated to only one lane of select highways or to vital traffic connector roads.

Traffic control: While traffic control barrier walls improve safety for drivers under typical conditions, at certain times of the day and under certain traffic conditions, such as the morning rush hour into the central business district, and the evening rush to residential communities, they preclude the flexibility of roadways to accommodate additional capacity. By application of floating barrier walls more lanes may be added to dense traffic as needed, adjusting the number of lanes per required traffic density and flow. These walls sink in or rise up dependent upon the flow of water in custom channels built to hold these walls.

\section{Further Discussion and Future Business}

Once developed and deployed, these innovations will serve primarily to improve safety and to save lives for both civilians and first responders. In addition to the private sector, applications for these technologies may be of interest to municipalities, and fire departments, state agencies, such as departments of transportation, federal entities such as FEMA, the US Army's Corps of Engineers, and the Department of Defense, as well as non-governmental organizations like the Red Cross. All of the above proposed solutions have been modeled, analyzed by the author, and some have been tested successfully. It is the author's hope to obtain opportunities for further research and mass production through further discussion and partnerships with private industry, government agencies and other related entities. 
(C) This work is licensed under Creative Commons Attribution 4.0 License DOI: 10.19080/CERJ.2020.11.555801

\section{Your next submission with Juniper Publishers} will reach you the below assets

- Quality Editorial service

- Swift Peer Review

- Reprints availability

- E-prints Service

- Manuscript Podcast for convenient understanding

- Global attainment for your research

- Manuscript accessibility in different formats

( Pdf, E-pub, Full Text, Audio)

- Unceasing customer service

Track the below URL for one-step submission https://juniperpublishers.com/online-submission.php 